\title{
Hannah Arendt and International Relations
}

This is a post-peer-review, pre-copyedit version of an article published in the Oxford Research Encyclopedia of International Studies.

Please do not quote from this version.

The final authenticated version is available online at:

https://doi.org/10.1093/acrefore/9780190846626.013.665.

\author{
Shinkyu Lee \\ sk.james.lee@gmail.com
}

\begin{abstract}
Summary
International relations (IR) scholars have increasingly integrated Hannah Arendt into their works. Her fierce critique of the conventional ideas of politics driven by rulership, enforcement, and violence has a particular resonance for theorists seeking to critically revisit the basic assumptions of IR scholarship. Arendt's thinking, however, contains complexity and nuance that need careful treatment when extended beyond domestic politics. In particular, Arendt's vision of free politics—characterized by the dualistic emphasis on agonistic action and institutional stability - raises two crucial issues that need further elaboration for IR research that appropriates her thinking. One involves the orientation of her international thoughts. Although Arendt shows "idealistic" aspirations for authentic politics practiced by diverse equals in an institutionally articulated space of freedom, she never loses interest in the extant situation of "non-idealistic" politics. Engaging with Arendt's theory orientation requires a careful analysis of difficult topics, such as her distinctive conception of the political and her critiques of the nation-state and international law. The other topic that needs clarification when Arendt's thoughts are applied to IR involves specific ways of associating different sites of power. A close examination of Arendt's council-based federalism reveals her distinctive idea of international politics, based on her acute awareness of the fundamental complexity that lies in power association and state agency. Bringing IR topics like state agency into conversation with her works generates illuminating questions for Arendt scholarship. Likewise, the ongoing debate on agonistic and institutional features of Arendt's thoughts can provide crucial insights into critical studies of international politics.
\end{abstract}

\section{Keywords}

Hannah Arendt, freedom, agency, idealism, realism, human rights, nation-state, international society, federalism, agonism 


\section{Introduction}

Hannah Arendt is one of the most prominent political thinkers of the twentieth century. Political theorists and practitioners alike have engaged with Arendt's attempt to restore an "authentic" form of politics, far from violence and enforcement, and viewed her thinking as particularly relevant in light of domestic and international threats to democracy, such as authoritarianism and imperialism. Arendt was a German Jewish émigré who spent most of her intellectual life in America. Having studied under two major figures of modern philosophy, Martin Heidegger and Karl Jaspers (Villa, 1996; Hinchman \& Hinchman, 1991; Grunenberg \& Daub, 2007), Arendt was initially interested in purely philosophical topics (Arendt, 1996; Young-Bruehl, 2004, pp. 74-76). Yet, her vivid experiences of the rise of Nazism in the 1930s as a persecuted Jew led her to become actively involved in politics (Arendt, 1994, pp. 45). Her writings are replete with nuance and complexity, making it difficult to affiliate her thoughts with a particular intellectual tradition. Arendt herself mentioned that inquiring about one's identification with an ideological force, such as liberalism or conservativism, is not illuminating but only obscures "the real questions of this century" (Arendt, 1979, p. 334). As several Arendt commentators point out, however, existential philosophy and civic republicanism form the broad background of her thinking (Villa, 2008a, p. 307; Benhabib, 2008, p. 15; Canovan, 1992, pp. 201-252; Kateb, 1984). These intellectual traditions serve to capture two major components of Arendt's thoughts_-agonistic action and institutional stability—and provide an analytical frame to show how her distinctive idea of free politics bears on a variety of contentious topics, such as freedom, sovereignty, power, authority, violence, and reconciliation (Goldoni \& McCorkindale, 2012; Hiruta, 2019; Gündoğdu, 2015; Kalyvas, 2008; Schaap, 2005).

Numerous critical commentaries and interdisciplinary works on Arendt's thoughts have been generated since her death in 1975. But, although Arendt's works cover international topics such as war, peace, world federation, imperialism, human rights, and global court (Arendt, 2005, pp. 153-191; 
Arendt, 2007b, pp. 423-450; Arendt, 1968, pp. 81-94; Arendt, 1972, pp. 105-123, 229-233; Arendt, 1973, pp. 123-157, 222-302; Arendt, 1963, pp. 253-279), the discovery of her thinking's relevance to the discipline of international relations (IR) was rather belated, as systematic examinations of her ideas from IR perspectives only started appearing in the mid-2000s (Owens, 2007; Hayden, 2009; Lang \& Williams, 2005). During this time, the debacles of the Iraq and Afghanistan interventions by the US and its Western allies were becoming clear, and voices opposing the combined forces of neoconservatism and liberal universalism behind American hegemony were growing loud in world politics. Arendt's fierce critique of sovereignty, along with her excavation of Greek agonism, gained much traction from critical and alternative IR theorists (Mitchell, 2010; Shinko, 2008; Owens, 2007, pp. 111-127; Wenman, 2013, pp. 263-297). Yet this focus, though rightly placed in that context, often rendered the appropriation of Arendt's thoughts partial and incomplete; accordingly, in their reception into IR scholarship, so-called "agonistic Arendt" tends to prevail over "institutional Arendt" (Honig, 1993a, pp. 76-125; Kateb, 2010; Waldron, 2000; Canovan, 1996a). A concern about this tendency is that Arendt's careful delineation of free politics appealing to both agonistic action and institutional stability is elided in the debate on adopting or resisting intervention and domination led by American global hegemony. Like many works that apply philosophical ideas to practical cases of politics, the crucial question for IR scholars who want to benefit from Arendtian insights into politics is how to make Arendt's thinking relevant to IR while preserving her theoretical rigor.

This observation on the IR reception of Arendt's thoughts highlights the importance of reflecting on the centrality of free politics to her thinking. In what ways, then, does her vision of politics differ from the conventional view? Before specific issues in which further clarification is needed to make an Arendtian case in IR are discussed, Arendt's basic insights into free politics must be articulated. 


\section{Free Politics}

Arendt's thinking is innovative in that it articulates free politics to enable modern individuals to view political phenomena or ideas that they have taken for granted in a different way. Best capturing Arendt's vision of free politics is her statement that "the raison d'etre of politics is freedom, and its field of experience is action" (Arendt, 2006a, p. 145). For her, then, the fundamental purpose of politics is to achieve freedom, and the method for its fulfillment is action. Arendt reaches this conclusion with the diagnosis that consistent prejudice against free politics exists in the Western tradition of political thoughts (Arendt, 1998, pp. 220-230; Arendt, 2006a, pp. 142-169). Indeed, many canonical theorists use the analogy of family, school, army, or corporation in describing political association. The key assumption among their theories is rulership: "the distinction between ruling and being ruled [or] between rulers and subjects" is "the essence of all political organization" (Arendt, 2007a, p. 945). Arendt acutely observes that the idea of rulership comes with the idea of a commanding will, or the "sovereign will" of the monarch, the aristocrats, or the people themselves. For Arendt, the sovereign will is deeply problematic because freedom can only be achieved via acting together, but the sovereign will is always unitary and negates plurality, the precondition of free politics. Arendt challenges this idea of rulership that exists at the foundation of political thinking's long tradition. Pointing out that freedom can appear only under the condition of non-sovereignty, Arendt notes, "If men wish to be free, it is precisely sovereignty they must renounce" (Arendt, 2006a, p. 163).

The anti-sovereign aspect of Arendt's free politics appeals to IR scholars who problematize the mainstream scholarship building on the principles of state sovereignty and international anarchy (Williams, 2002; Axtmann, 2006; Barder \& Debrix, 2011). Yet, the ensuing issue is how to achieve this ambitious vision of free politics, one that goes well beyond rulership, domination, and violence. Arendt's approach avoids the usual path of Kantian universalism, or the so-called Kantian "perpetual peace" (Kant, 1983; Doyle, 1983). Cognizant of the limit of abstract ideas such as global humanity, 
Arendt greatly appreciates the contingent aspects of public worlds and attends to tangible local contexts of politics. Thus, even when Arendt refers to "cosmopolitan existence" in her lectures on Kant, her use of the term cautions against the misuse of the idea of humanity (Arendt, 1982, p. 76; Owens, 2010, p. 73). Instead, Arendt thinks the key to free politics is action, though much caution is needed when applying her action theory to the setting of international politics. Before this crucial topic is analyzed for IR, however, it is necessary to elaborate the basic principles of action in her thinking and demonstrate how they fulfill the vision of free politics beyond rulership, enforcement, and violence.

The main argument of Arendt's action theory is that labor, work, and action constitute the vita activa (human activities) and that their differences need proper attention (Arendt, 1998, pp. 79-247). The activity of labor "corresponds to the biological process of the human body" as it produces necessary resources for individual and human species' survival, whereas the activity of work provides “an 'artificial' world of things, distinctly different from all natural surroundings" (Arendt, 1998, p. 7). For Arendt, action is crucial for what she considers authentic politics because it can go on "without the intermediary of things" and is most compatible with the condition of human plurality (Arendt, 1998, pp. 7-8, 180, 184). By making these distinctions, Arendt does not suggest that any of these activities is inherently inferior. For her, labor, work, and action each has its own significance for human existence (Arendt, 1998, pp. 8-9). However, Arendt also identifies the “inverted hierarchy” prevalent in modern society, according to which labor is considered the first source of value and work the second, while politics is "mere speech" that contributes nothing of value (Arendt, 1998, pp. 294-325). In light of this hierarchy, Arendt finds a clear motive to emphasize action. Seeing that prejudices against action created the environment for the rise of totalitarianism's anti-politics, she finds it imperative that individuals become cognizant of the meaning and dignity of political action, the activity most compatible with the human condition of natality and plurality (Canovan, 1992, p. 103; Villa, 
1999, pp. 202-203). To recover the specifically political meaning found in action, Arendt turns her attention to the experience of the Greek polis. As one commentator notes, her Greek engagement “bring[s] forth, in 'crystallized' form, the phenomenological bases of politics as practiced by diverse equals in a public space" (Villa, 2007, p. 985).

Arendt calls the gradual process culminating in the inverted hierarchy of modern society's vita activa "the rise of the social" (Arendt, 1998, pp. 38-49). This historical side of Arendt's judgment broadly shares postmodern, postcolonial IR theories' critical insights into modern consumerist culture and the neoliberal market economy in that, like those theories, it also urges political actors to see the fundamental, structural sources of domination for modern politics (Jones, 2013; Chandler, 2010; Amin, 2014; Mitchell, 2014). Yet, in addition to the diagnostic observation of the modern world, Arendt's theoretical scheme highlights a complex aspect of action that requires detailed explanation.

According to Arendt, action has two features (d'Entreves, 1994, p. 84; Villa, 1996, pp. 54-55; Benhabib, 1996, p. 125). One is disclosive. Unlike work, which entertains a particular end or value, and labor, which absorbs everything into a cyclical life process, action shifts the focus to the uniqueness individuals reveal through performing "great" words and deeds in public (Arendt, 1998, p. 179). In this scheme, then, actors are not those who claim to know some truths about themselves and announce them in public (Owens, 2007, pp. 16-20; Schaap, 2005, p. 64). The other aspect of action Arendt has in mind is associational. It is grounded in the fact that to be heard, one's speeches and actions need an audience that consists of diverse equals who foster plural perspectives on the public matter. By being inserted into a "web" of human relationships, action generates a series of reactions among people and their stories and creates new relationships (Arendt, 1998, p. 183).

These two aspects of action show how action-driven politics eschews rulership and domination. If the disclosive action serves to avoid the environment where individuals enforce predetermined sovereign wills in a public space, the associational action points to the contingent 
politics that happens as engagements with others' actions and stories mediate individual action. Because action resists assuming any knowledge about individuals before they appear in public and enacts stories in an intersubjective manner in which individuals become both "actors" and "sufferers" through storytelling, the sources of domination are effaced in action-driven politics (Arendt, 1998, pp, 184, 190).

How action eschews domination is even more evident in a communal context of politics: power formation. Defining power as the ability to act together, Arendt draws on quite a different idea of power than the conventional view that considers power in terms of command and obedience and equates power with violence (Arendt, 1972, pp. 143-155; Arendt, 1998, 199-207; Volk, 2015, pp. 180195). Because power manifests itself in such a communal action, it cannot be the property of an individual but "remains in existence only so long as the group keeps together" (Arendt, 1972, p. 143). Of course, in tyranny, a single ruler may control people, but, viewed from Arendt's perspective, this is not because the ruler is powerful. The only way one can restrain many is to use violence, and thus the ruler is violent, not powerful (Arendt, 2006b, p. 142). The generation of true power depends on the living together of people; the real status of power can be judged by the extent to which people seek to come together for public talk and action. "[P]ower comes into being," Arendt notes, "only if and when men join themselves together for the purpose of action, and it will disappear when, for whatever reason, they disperse and desert one another" (Arendt, 2006b, p. 166). Thus, the so-called "power" found in the repressive practices of authoritarian regimes is not genuine to Arendt. It in fact testifies to the leader's or the regime's true impotence. If power only appears among those individuals who experience their uniqueness and connectedness through acting together, domestic repression and violence will be abolished or significantly alleviated under the aegis of action-driven politics.

Arendt's articulation of action and her reformulation of power demonstrate how politics can avoid extreme existential confrontation—represented by what Carl Schmitt calls "the friend and 
enemy distinction" - and the violence it entails while keeping the public realm filled with citizens who exchange their opinions from different perspectives on a common issue (Schmitt, 1996; Owens, 2011; Kalyvas, 2008, pp. 194-231). Her critique of the conventional conception of violence as inherently attached to politics and her distinction between violence and power are deeply informed by the events of her own time. "Totalitarianism and the [atomic] bomb," in particular, are "linked in Arendt's mind as the two fundamental experiences of her time" (Canovan, 1992, p. 79). For her, the idea of "total war" that either totalitarian terror or full-scale thermonuclear war harbors goes far beyond the Clausewitzian approach that views war as the continuation of politics by other means (Arendt, 2005, p. 199-200; Owens, 2007, p. 6). Opposing national security policies that assumed unlimited warfare at the peak of the Cold War, Arendt points out the need to secure the bounds of politics in isolation from violence (Arendt, 2005, p. 159). Likewise, interacting with various incidents of her time, including the Hungarian Revolution, decolonization of Asia and Africa, Civil Rights Movement, and antiVietnam war demonstrations in America, Arendt critically questions the close relationship between violence and power or politics. By so doing, she confirms the feasibility of authentic political action in spontaneous popular uprisings while warning against any (military and anti-colonial) approaches that exaggerate the strategic and therapeutic value of violence (Arendt, 1958; Arendt, 1972, pp. 3-47, pp. 105-198; Arendt, 2006b, pp. 1-10). The overall point of Arendt's comments on these events is the importance of action, not violence, as a method for fulfilling freedom, which she considers the purpose of authentic politics.

Importantly, however, Arendt does not deny that action-driven politics faces problems. As several Arendt commentators point out, agonism accompanied by action was a matter of concern for Arendt (Canovan, 1992, p. 133; Villa, 2008a, p. 306; Tsao, 2002). This is evident in her observations on ancient Greek life. Seeing that Achilles' heroic words and deeds pursue "self-disclosure at the expense of all other factors," Arendt warns that action can lead to an intensely agonal competition for 
the disclosure of uniqueness (Arendt, 1998, p. 194). In light of action's two features, then, Arendt's concern is that the disclosive, or what some call the "dramaturgical," aspect of action overwhelms its associational demand in the context of intense agonism (Wolin, 1990, p. 191, n3). Even without the "highly individualistic" type of action seen among Homeric heroes, Arendt makes it clear that free politics driven by action is precarious because the outcome of action is boundless and unpredictable (Arendt, 1998, p. 194). By always falling into "an already existing web" of human relationships, action tends to "force open all limitations and cut across all boundaries" (Arendt, 1998, pp. 184, 190). For Arendt, this boundless feature of action serves to reflect new voices and establish relationships (Arendt, 1998, p. 191). As Margaret Canovan notes, however, Arendt clearly sees that action's boundlessness creates a lack of stability, and thus she seeks to minimize the problem by appealing to the importance of institutional limits for free politics (Canovan, 1992, p. 143). A similar argument is found in Arendt's recognition of power's limitations. In On Revolution, among other works, Arendt argues that the underlying foundation of power and its preservation is the activity of promising. But Arendt also adds that "neither compact nor promise upon which compacts rest are sufficient to assure perpetuity, that is, to bestow upon the affairs of men [a] measure of stability" (Arendt, 2006b, p. 174). Thus, while providing the phenomenological account that power is derived from acting in concert on the basis of mutual promises, Arendt ascertains that free politics needs to have reliable sites of power and "lasting institutions" to enable human beings to achieve the greatness of public culture and civilization (Arendt, 1998, p. 197; Arendt, 2006b, p. 221). In broaching this issue, Arendt confirms that without stable institutions, action is fleeting, and power is easily dissipated.

The complexity found in Arendt's free politics suggests that her thoughts are a theory of limits as well as of beginnings and disruptions. Despite her fascination with the initiatory dimension of action and the non-violent character of what has come to be called "people power," Arendt never ignores the importance of institutional, communal limits for politics. This dualistic side of her thinking renders 
it separate from ideological, cosmopolitan pacifism (Arendt, 1973, p. 442; Howes, 2013; Reader, 2007) while generating a debate on the scope of aesthetic action and non-violent power-whether these Arendtian principles have much relevance to the dimension beyond the clearly demarcated arena of politics or whether that dimension is merely pre-political for Arendt (McGowan, 1997, p. 291; Frazer \& Hutchings, 2008, p. 102; Ashcroft, 2018, p. 133). Given the ongoing discussion on the IR implications of Arendt's thoughts, however, the following explores two major questions. The first is about the orientation of Arendt's free politics. Is Arendt's aspiration for freedom (achieved among diverse equals in the public realm) idealistic, or is it able to reflect "real" politics? Second, what specific forms of political association do Arendt's free politics foster? What follows will show that articulating these issues is crucial in making an IR case for Arendt's thoughts by grounding the analysis in her discussions of the nation-state and international law and of council-based federalism.

\section{The Ideal vs. the Non-Ideal}

The terms "ideal theory" and "non-ideal theory" find their origin in John Rawls's book $A$ Theory of Justice (Rawls, 1999), although, as Laura Valentini points out, what really triggered further studies of this area was the frustration that the Rawlsian paradigm is "too detached from reality to guide political action" (Valentini, 2012, p. 654). Recently, these methodological issues have come to the fore in international political theory. This is particularly pronounced in the renewed interest in political realism and its combination with radicalism against abstract liberal cosmopolitanism (Miller, 2016; Bell, 2017; Hall, 2011). At first glance, the concern about Rawls's Kantian methodology has nothing to do with Arendt. Her method for free politics is action, and action always occurs among actual people, not with imaginative entities set up for constructing a moral conception of justice. But Arendt's thoughts have been charged with idealism. Critics claim that Arendt's sense of politics is too narrow and that the autonomy of the political found in her argument isolates her free politics from socioeconomic matters, 
without consideration of which politics is rather "empty" (Pitkin, 1998; cf. Owens, 2012). The critique often comes with the charge of Graecomania: With her admiration of the Greek experiences of politics and action, Arendt makes a futile attempt to revive ancient pure politics in the modern world (Jay, 1986; Parekh, 1984; Wolin, 1994).

\section{On the Political}

Arendt's strict distinction between the political and social spheres is not difficult to find in her works. In The Origins of Totalitarianism, Arendt describes the bourgeois pursuit of endless accumulation and growth as a primary culprit in the rise of overseas imperialism and the resulting destruction of political structures in late-nineteenth-century Europe (Arendt, 1973, pp. 123-157). Here, Arendt points out the fundamental difference between political and social realms by noting that "the political structure ... is not based upon the productivity of man" (Arendt, 1973, p. 125). In The Human Condition, while arguing that the cyclical life process has a close connection with the social, Arendt defines society as "the form in which the fact of mutual dependence for the sake of life and nothing else assumes public significance" (Arendt, 1998, p. 46). Seeing that the rise of society created the conditions under which the life process was channeled into the public realm and led to the deformation of politics, Arendt urges against mingling the political and the social (Arendt, 1998, pp. 45, 46). The broad theme of this argument continues in On Revolution (Arendt, 2006b, pp. 49-105). Reflecting on the French Revolution, which was swept by the social question of poverty, Arendt attributes its fundamental failure to the revolutionaries' lack of attention to the fact that "the cares and worries ... of the household ... could not be solved by political means, since they were matters of administration” (Arendt, 2006b, p. 81).

However, whether these are examples of Arendt's ignorance of socioeconomic matters or even instances of her political idealism is questionable. One may argue that the real point of Arendt's Greek engagement is methodological, not strictly prescriptive: Arendt uses the polis experiences as a 
heuristic device to articulate the traces of authentic politics, according to which the modern can see what has been lost in their ideas and practices of politics (Villa, 2007, p. 985). The purpose of Arendt's inquiries is not to identify an ideal model of politics in ancient Greek history and transplant it into the modern world but to generate critical questions regarding conventional political senses and activities. Douglas Klusmeyer aptly captures this reformist orientation of Arendt's thoughts, which he calls “critical realism” (Klusmeyer, 2005). Similarly, Ayten Gündoğdu, while applying Arendtian insights to human rights issues that often cross the political and social distinction, argues that Arendt's thinking points out the need for "practices of translation" to politicize socioeconomic matters (Gündoğdu, 2015, p. 15). Gündoğdu's well-taken point can be supplemented by the observation that in some socioeconomic issues, the criterion of productivity evidently prevails, and the political standard of continuous debate and deliberation carries no value. When politicizing those areas or topics, then, one always has to keep in mind the danger posed by the infiltration of the social into politics.

The discussion so far has revolved around the methodological nature of Arendt's Greek engagement. Yet, some scholars question whether the Greek politics of action really serves as a model for Arendtian free politics (Tsao, 2002, pp. 105-116; Ashcroft, 2018, pp. 132-138; Volk, 2010, pp. 774779). According to this view, Arendt's ideal is not Greek politics. Her judgment on the polis experience says that even when a certain balance between disclosive and associational aspects of action is present, a public space of appearance cannot "endure [and] survive the moment of action and speech" because action is inherently boundless (Arendt, 1998, p. 198). This critical observation leads to the interpretation that with her acute awareness of the problems associated with action, Arendt does not advocate a pure politics of action. Instead, her thinking entertains a qualified form of politics to minimize the unpredictability of action by having it reliably appear in an institutionally articulated space (Waldron, 2000, p. 213; Villa, 1999, p. 118). What comes to the fore here is the contested status 
of law and institutions in free politics because, although institutions provide stability for politics, they can also place restraints on "the possibility of new action" (Keenan, 1994, p. 309).

Patchen Markell details this topic by exploring the ambiguity of work in Arendt's terrain of the political (Markell, 2011). Whereas work creates a relatively stable world of institutions enabling the reliable appearance of action, it can also do violence by making artifacts according to the means-andends reasoning. If two features of work (stability-generating and instrumentality-driven) exist on a continuum in Arendt's thinking, such known dichotomies as "the political and the social" and "action and labor" are simplistic, and mingling these juxtapositions is problematic (Lee, 2021, pp. 89-90). A better way to capture Arendt's intention is to formulate "two different pairs of concepts" —workaction and work-labor-because this reconstruction highlights a dynamic aspect of free politics (Markell, 2011, p. 18). According to Arendt, then, free politics needs institutions that contain work's demarcating feature, since they tame intensely agonistic action and protect politics from natural or quasi-natural forces such as those generated by the capitalist system of production and consumption. It also requires action's consistent inputs, without which institutions' ossification and subjection to the circularity of labor and the life process are difficult to avoid.

\section{Critique of the Nation-State}

These issues about the orientation of Arendt's political thoughts closely relate to the issue of how to place nation-states in free politics. Contra cosmopolitan aspirations, sovereign nation-states still remain the main constituents of international politics. However, statist frameworks about world politics fail to incorporate an emerging global polity into international discourse. Depending on their scholarly orientation, as Chris Brown points out, theorists vary as to what order of world politics is to be normatively privileged (Brown, 2015, pp. 11-14). Considering the complexities that lie in Arendt's 
distinctive idea of political and social realms, then, questions regarding her conception of and overall attitude toward nation-states arise.

Arendt is a fierce critic of nation-states. In The Origins of Totalitarianism, among other works, Arendt blames those nation-states that abused their sovereign powers and denationalized vast numbers of Jews and other minorities and members of the political opposition (Arendt, 1973, pp. 267-302). Going further, Arendt charges the nation-system itself with failing to deal with the ensuing crisis of stateless people (Benhabib, 2002, pp. 542-547; Krause, 2008, pp. 337-338). From these accounts, it is tempting to establish a Kantianized Arendt who would endorse a human rights universalism. In the same book, however, Arendt claims that having "some kind of organized community" is essential for human rights implementation (Arendt, 1973, p. 294). For her, the most fundamental deprivation of human rights occurs with the absence of "the right to have rights," that is, when no tangible space that "makes opinions significant and actions effective" is available (Arendt, 1973, p. 296). Yet, considering Arendt's approving remarks on the establishment of an international criminal court and call for international federation (Arendt, 1963, p. 269; Arendt \& Jaspers, 1992, p. 416; Arendt, 1968, p. 93), her critical judgement of human rights does not dismiss their value for international discourse aiming at the solidarity of humankind. Rather, her critique suggests that human dignity is conditional; it can be ensured only when individuals recognize each other as co-builders of a common world through speech and action (Arendt, 1973, p. 458; Macready, 2016, p. 410). The intended effect of acknowledging "the instability of human dignity" this way is to make human rights inquiry "pragmatic and historical" rather than merely "presumptive and aspirational" (Weinert, 2015, pp. 22-23). Highlighting political conditionalities for human dignity also means that presenting Arendt's totalizing critique of nation-states via Kantian universalism is problematic because providing territorial limits and forming a membership — the conditions that facilitate the exchange of opinions and the public appearance of actions — are part of nation-states' functions (Cohen, 1996, pp. 170-171). 
Of course, Arendt raises deep concerns about "the tragedy of the nation-state" that occurs when the nation prevails over the state (Arendt, 1973, p. 230). Pointing out "the perversion of the state into an instrument of the nation," Arendt maintains a critical tone against nation-states (Arendt, 1973, p. 231). However, nowhere can one find her strong endorsement of a world state aspiring to "a completely organized humanity” to resolve human rights issues (Arendt, 1973, p. 299).

Such an "aporetic" aspect of Arendt's thoughts has prompted several scholars to align her thinking with a mild version of cosmopolitanism. Notably, James Ingram argues that Arendt's objection to world government does not extend to all possible types of globalism. The size of the government is not the point; what Arendt problematizes is how a global polity actually operates (Ingram, 2008, p. 409). As long as global governance empowers local capacities for politics in a "bottom-up" manner, there is no reason to object to it. Similarly, Seyla Benhabib seeks to relieve Arendt's anti-cosmopolitan concern by pointing out that global norms like human rights are not put into practice in a single top-down mode. Rather, they go through "democratic iterations" or complex processes of public deliberations occurring at or through a variety of political institutions and social networks (Benhabib, 2009, p. 691-704). Yet, there has been a question of whether global engagement with the local has been shallow. Critics ask if such an engagement with sources of local differences focuses on developing strategies for promoting values envisioned in a liberal cosmopolitan agenda (Hayden, 2009, pp. 117-118; Jean-Klein \& Riles, 2005; Gourevitch, Lake, \& Stein, 2012). One may agree that "the problem is not one of scale, but of form [of global governance]" (Ingram, 2008, p. 409). However, whether loophole-related power imbalances become frequent when the system of governance expands and how teleological progressivism implied in cosmopolitan renditions of jurisgenerative politics makes possible a strenuous dialogue regarding sources of local differences are ongoing topics of concern (Brown, 2012, p. 224; cf. Benhabib, 2007, p. 456). To be clear, locality is not what nation-states can best represent, although they are not separable from it. At any rate, Arendt's 
anxiety about the depoliticizing effect of a global regulatory system on locality is worth invoking in cosmopolitan approaches to world politics.

Another way of constructing an Arendt congenial to human-rights-based governance is to revisit her anti-foundationalism. Theorists like Peg Birmingham point out that "[Arendt] remains within the framework of a "weak ontology,"” which is not comparable to strong metaphysical claims about the unchanging nature of human beings (Birmingham, 2014, p. 709; Birmingham, 2006, pp. 1217). Taking a cue from Arendt's discussion of "principles" facilitating action as opposed to "goals" or “ends" (Arendt, 2005, pp. 193-200; Muldoon, 2016), these approaches repudiate the claim that Arendt is an anti-foundationalist in a strict sense and argue that her "new political principle" refers to the fundamental human condition that renders politics (of action) possible (Arendt, 1973, p. ix; Birmingham, 2014, pp. 705-710; Benhabib, 2010, p. 222). Arendt's statement in Eichmann in Jerusalem that "[genocide] is an attack upon human diversity as such" is the key source for making this move (Arendt, 1963, pp. 268-269). Arendt's judgment that the denial of human plurality found in Eichmann's behaviors is the reason he ought to be punished reveals her understanding that the principle of plurality grounds international law and human rights.

A central concern in Arendt's thoughts is the nature of evil. Arendt is known to develop two seemingly conflictual ideas of evil: "radical evil" and "the banality of evil" (Arendt, 1973, p. 459; Arendt, 1963, p. 252). Harms of radical evil, for her, cannot be reduced to any recognizably human motivations (Arendt \& Jaspers, 1992, p. 166). Arendt associates radical evil with the totalitarian Nazi because its "total terror" is characterized not by the "limited" aim of an individual tyrant's or regime's survival but by the unprecedented attempt to make humans superfluous. If radical evil "transcend[s] the realm of human affairs," then it is neither punishable nor forgivable but a matter to be addressed through God's retribution (Arendt, 1998, pp. 240-241). Yet, although this description brings forward a novel form of harm represented by the concentration camps, it inadvertently grants the totalitarian 
regime metaphysical depth and ambition it does not deserve (Arendt \& Scholem, 2017, p. 209). The "banality of evil" thesis, referring to a thoughtlessness revealed in Eichmann's behaviors, seeks to avoid this problem by denying a force or agency that transcends human individuals and "bring[ing] the deeds of the perpetrators within the horizons of human judgment and human law" (Villa, 1999, p. 56).

Confirming that the aim of the Eichmann trial should have been the dispensation of justice for individual deeds, Arendt disapproves of the Israeli government's use of the court as a case for national education (Arendt, 1963, p. 5). Instead, she endorses the idea of an international penal code to address crimes against humanity—attacks on human plurality, the most fundamental element of the construction of public worlds (Arendt, 1963, pp. 261-262). Handling this "cosmopolitan" side of Arendt's thinking, however, requires proper caution. First and foremost, whether anything similar to the moral idea of equal human rights can be deduced from the mere fact of plurality is questionable (Canovan, 1992, p. 198). Although Arendt makes a modest recommendation to establish "universal mutual agreements" among states that recognize human plurality, this differs from an endorsement of procedures to enforce comprehensive moral norms worldwide (Arendt, 1968, pp. 93, 90). Even conceding the point that the destruction of plurality is the most evil of politics, questions about what particular act warrants this criminalization remain to be examined (Owens, 2007, p. 49). The problem is that, as some Western countries' attitudes toward radical Islamists show, such concrete issues are often submerged under abstract slogans of resistance, such as "war on terror," without careful political judgment. Arendt herself cautions against indiscriminately treating all ideological hatreds as manifestations of radical evil and targets of international intervention (Villa, 2008b, pp. 103-109). Finally, Arendt makes the important qualification that invoking cosmopolitan humanity in times of persecution is not always adequate (Luban, 2015, pp. 317-324). Besides endorsing the creation of a Jewish army against Hitler, Arendt also notes that "[i]f one is attacked as a Jew, one must defend 
oneself as a Jew" (Arendt, 2007b, pp. 136-139; Arendt, 1994, p. 12). This is not to justify counterpersecution or nationalistic thinking. Nonetheless, this line of thoughts reflects the broad insight derived from Arendt's (not fully cosmopolitan) interest in real-world practices of resistance, punishment, and reconciliation that will not destroy the bounds of politics (Owens, 2007, pp. 20-25; Lang, 2008, pp. 102-110; Schaap, 2005, pp. 71-79).

\section{Beyond Kantianism}

Beyond the Kantian human rights framework, some scholars argue that the real strength of Arendt's thoughts lies in its open-ended nature (Gündoğdu, 2015, pp. 29-36). According to this approach, Arendt's arguments about human rights point to "the right to politics," which is, in effect, a right to political action (Ingram, 2008, p. 411). Here, action's boundless feature comes to the fore as a way of revealing excluded and marginalized voices. Rather than attending to the hackneyed issue of what grounds human rights, Arendt's aporetic method brings forward the generative aspect of human rights that serves to "articulate new rights or bring to view new subjects entitled to rights” (Gündoğdu, 2015, p. 22). The innovative argument of this kind, however, tends to underrate the issue of who or what would be a reliable entity for dealing with global issues. Being attentive to perplexities that lie in global problems, such an agonistic rendition of Arendt certainly increases sensitivity to the importance of identifying new ideas or subjects. Yet, as David Miller identifies, a crucial question for global political theory is who would implement ideals of justice internationally (Miller, 2016, p. 224). Arendt's free politics is never ignorant of the agent problem. For this issue, one must be reminded of her observation that action and power need institutions that provide them with stability and durability (Arendt, 2006b, p. 174; Arendt, 1998, p. 197). This implies that Arendt thinks human rights engagements without reliable sites of power and lasting institutions are limited. Regarding human rights issues, including refugee crises, then, Arendt's thoughts not only question how to recognize new 
entities for rights but also how to form a durable power to address those problems while enlarging the scope of solidarity for power (Hayden \& Saunders, 2019; Horst \& Lysaker, 2019; Miller, 2007).

The last point brings the discussion back to the question of nation-states' status in free politics. Scholars such as Margaret Canovan highlight complexities in Arendt's thinking about nation-states that readings based on her passing statement that they are "outdated" may not fully capture (Canovan, 1999a; Beiner, 2000; Arendt, 1973, pp. 147, 232). According to this view, Arendt's thoughts illustrate the advantages that nation-states provide. One major merit among them is that nation-states act as bulwarks against proto-totalitarian forces. This is evident when Arendt claims that national institutions in the early stage of European imperialism served to "resist the brutality and megalomania of imperialist aspirations" and impeded "bourgeois attempts to use the state and its instruments of violence for its own economic purposes" (Arendt, 1973, p. 124). Another merit worth noting is that nation-states act as reservoirs of political power (Canovan, 1996b, pp. 72-75; Miller, 2008, p. 147; Goodman 2017). On this reading, Arendt's acknowledgment of fleeting action and easily dissipated power points to the need not to dismiss lightly the role of nationhood as a battery for generating stable power (Canovan, 1999a, p. 109). Aside from the concern about the misuse of such a power, however, the approach that renders Arendt congenial to nation-states faces the obvious interpretive challenge that she explicitly critiques them in many of her works. In addition to her charge against nation-states for stateless people, Arendt portrays them as a political form of the social by arguing that they operate “a gigantic, nation-wide administration of housekeeping” (Arendt, 1998, p. 28).

One way of mitigating this difficulty is forming two types of nationalism and arguing that whereas Arendt endorses a chastened form of nationhood, she criticizes a type of nationalism that considers states to be biological rather than cultural and historical entities (Canovan, 1999b, pp. 134138). "Organic" nationalism—-the main target of Arendt's critique-rests on "an identification of the nation and the relationships between its members with the family and family relationships" (Arendt, 
1998, p. 256). It differs from a worldly kind of nationhood that can animate what Arendt would call the "care for the public realm" (Arendt, 1998, pp. 50-58). Such a differentiation underscores the precariousness of political structures, including nation-states, which can always go in a wrong direction. Yet, the problem with this rather neat distinction is that Arendt's thoughts on nation-states at times show more interest in their dynamics in concrete situations than in labeling them "good" or "bad." In The Origins of Totalitarianism, for instance, Arendt notes that as the Chinese leaders "clearly recognized national interest" and fostered nationalist sentiment, the Maoist government was able to avoid the path of total terror the Stalinist regime had taken (Arendt, 1973, p. xxvi). The accuracy of Arendt's description of the dictatorial Maoist regime aside (Baehr, 2010a, pp. 274-280), statements like this suggest her "non-idealist" orientation. Although Arendt is certainly not giving up aspirations for authentic politics, such complexities in her judgment of nation-states attest to her interest in reforming available political structures. This "realist" concern should be taken as seriously as Arendt's "idealist" vision for pure politics. Indeed, given the contested status of nation-states in contemporary world politics, engaging with such a dualist orientation of Arendt's thoughts would be illuminating for making an Arendtian case in IR.

\section{The Domestic vs. the International}

Another area in applying Arendt's thinking to IR that requires further clarification is how different sites of power are to be connected at the international level. Arendt details the formation of power, such that " $[\mathrm{t}]$ he way the beginner starts whatever he intends to do lays down the law of action" (Arendt, 2006b, p. 205), and the new principle derivative of that action inspires others to follow the initiator and create a joint enterprise. For Arendt, power created this way and its consistent presence are preconditions for founding a new space for politics nonviolently (Arendt, 2006b, pp. 166-167). Yet, because multiple sites of power are conceivable in this scheme, the ensuing questions concern how 
powers are associated and what the basic unit of that association is. These questions about power association relate to the important debate in IR scholarship on state agency, i.e., the scope of states' ability to engage with each other (Jackson, 2004, p. 285; Miller, 2016, pp. 223-226; Wight, 2004; Lang, 2002). What are the advantages and disadvantages of taking the state as the constitutive actor of international politics? How does free politics attend to the "structural" dimension of the state while keeping individual citizens' agency intact? Arendt's federalism is crucial for engaging with these topics; Arendt finds the federal system effective for associating powers (Arendt, 2006b, p. 159). Fundamental to her federalist thinking is the belief that the federated republic can avoid the centralization of power and the reduction of local potency for politics and the situation where "the allied powers" of the local units "cancel one another out" (Arendt, 2006b, p. 144).

\section{Power Association}

Scholars have critically engaged with Arendt's distinctive idea of power association. Agonistic theorists, in particular, claim that Arendt's theory of action and power assumes the integrity of the public sphere. By comparing Arendt's call for public action with Nietzsche's aesthetic individuation, for instance, Bonnie Honig suggests that the unruliness of action and its resistance to being captured by any communal perspective should be preserved at the individual level (Honig, 1993a, pp. 61-65, 115-125). Her concern is that unless it goes through the Nietzschean self-transformation that prepares individuals to challenge deep-seated forms of social and political domination, the Arendtian way of acting in concert "risks sliding into mass behavior" (Honig, 1993b, p. 532; see also Honig, 2009, pp. 112-180). On this reading, "all institutional settlements generate remainders," and the only method for eschewing this problem is to commit to "the perpetual generation of new sites of action in concert" (Honig, 2009, 133). Honig envisions the global rendition of this approach as an "agonistic cosmopolitics," a way approximate to "global social movements" (Honig, 2009, p. 129). The approach 
often dubbed "radical agonism," which informs Honig's interpretation of Arendt, is highly influential in research on resistance and intervention. Thus, some critical engagements with global justice theory appeal to the contingent basis for and unpredictable forms of global-local encounters (Robinson \& Tormey, 2009; Björkdahl \& Höglund, 2013; cf. Kohn, 2013). Innovatively, they call for assuming "the constant pluralization of subjects and ideas" as an alternative to overcome the neoliberal, Western framework that sets the terms of the construction and relations of the global and the local (BarguésPedreny, 2017, p. 228; Ba, 2017).

Considering Arendt's dualistic emphasis on agonistic action and institutional stability, however, one can ask to what extent radical agonism's rendition of Arendt remains within her theoretical scheme. In contrast, readings such as Patchen Markell's analysis bring sharp clarity to "institutional Arendt." By conceiving of the relationship between the activities of demarcating work and disruptive action as that of "provocation and response between things in their meaningful appearances," Markell insightfully proposes that for Arendt, worldly artifacts of all sorts-individual objects and collective institutions-coexist and are connected through the phenomenological process of constant appearance (Markell, 2011, p. 36). Taking a cue from Arendt's discussion of storytelling, some theorists extract a similar insight from her thoughts and claim that for Arendt, all possible actors and objects on the international scene form equal narratives that are constantly connected and reconnected through storytelling across their sites of origin (Benhabib, 2007, pp. 454-456; Benhabib, 2009, pp. 697 699). Presented as such, Arendt's thinking becomes close to narrative IR theories that accentuate the intersubjective dimension of international politics (Neumann, 2004; Ringmar, 1996; Weber, 1998; Williams, 2015, pp. 51-57).

Yet, two critical questions arise regarding this interpretive move. First, are institutions mere objects that await being swayed by actors who demand social and political changes and agonistically compete for their public appearances, according to Arendt? Her appreciation of law is worth 
mentioning here: "Politics deals with men, nationals of many countries and heirs to many pasts; its laws are positively established fences which hedge in, protect, and limit the space in which freedom is not a concept, but a living, political reality" (Arendt, 1968, pp. 81-82). In comparison with those proposed interpretations, Arendt's thinking tends to have much more appreciation for the ground of a "care for the world," from which action reliably appears, and human civilization is possible (Arendt, 1998, p. 197; Arendt, 2006b, p. 221). Put differently, Arendt does not consider participation in the world of institutions to be a reluctant yet inevitable matter for making "desirable changes" (Coles, 2016, pp. 175-176). Nor does juridical engagement driven by her vision of politics merely focus on developing strategies to use institutions for political changes.

The second area of discussion, which is related to the first, concerns whether all human artifacts are considered equal in Arendt's free politics. Her characterization of the public realm as "the common meeting ground" of distinctive individuals suggests that some human artifacts are more public than others (Arendt, 1998, p. 57). For example, the constitutional state is a collective kind of worldly artifact designed to provide stability for politics while facilitating the reliable appearance of political actions. Notable here is that owing to the internal demand for stability, the constitution cannot be perpetually open to change; this would decrease internal stability and may be inconducive to making opinions significant and actions effective (Arendt, 2006b, p. 148; Arendt, 1998, p. 191; Arendt, 1973, p. 296). Thus, the constitutional state has an independent dimension once it is created. Certainly, openness is observed at individual and collective levels of Arendt's free politics. But, when the self is decentered for action and the bounded law is provoked to refigure itself to integrate disruptive voices for change in Arendt's theoretical scheme (Arendt, 1998, p. 179; Arendt, 2005, p. 183; Villa, 1996, pp. 89-99; Volk, 2015, pp. 215-221), the rates of change are not the same. Change at the collective level is much slower than change at the individual level (Canovan, 1974, p. 83). This implies that the narrativist rendition of Arendt's thoughts on power association, namely, equalizing all conceivable units of free 
politics as stories to be connected, is problematic, for it overstates the similarity between boundless action and relationship-generating law while obscuring the challenges that the internal demand for the reliable appearance of action creates for the external demand to establish new relationships with others.

\section{International Federation}

Similar issues in the relationship of action, power, and law can be raised regarding the international application of Arendt's arguments about federalism. Several works in Arendt studies engage with international federation, or what Arendt envisions as "a world-wide federated structure," by tracing her writings on postwar European reconstruction and Israel-Palestine relations (Arendt, 1968, p. 93; Rubin, 2015; Selinger, 2016; Ashcroft, 2017; Lederman, 2019). Early IR scholarship that attends to Arendt's thoughts seldom elaborates the international implications of her federalism (Owens, 2007, p. 145; Hayden, 2009, p. 26; Lang \& Williams, 2005). Roland Axtmann's work is a rare example, bringing forward Arendt's interest in the representation of the Jewish nation via federation (Axtmann, 2006, pp. 107-112). Indeed, what has emerged from historical research on Arendt's federalism is that her writings in the 1940s strongly suggest that the base of European integration she supports does not lie in individuals (morally tamed by some kind of universalism) but in nationalities. Driving this vision of federalism, as William Selinger articulates, is Arendt's expectation that in a federal structure of European nations with its own parliament, Jews can be recognized and represented as a nation (Selinger, 2016, pp. 421-431). Arendt considers a consecutive, multi-level model of federalism in which a federation in Palestine is part of higher federations in the Middle East, the Mediterranean region, and even Europe (Arendt, 2007b, pp. 196-197). This way, she envisions both nations of Jews and Arabs can enjoy equal group rights as members of a larger system, and therefore choosing a sovereign ruler over Palestine will become unnecessary. 
None of the works on Arendt's federalism argue for the nation without qualification when presenting it as a constituent of international federation. As Arendt's statement that “[w]ithin federated structures, nationality would become a personal status rather than a territorial one" evinces, the nation she considers for federation is not territorial (Selinger, 2016, p. 424). Moreover, a shared past or "organized remembrance" primarily conceived of as "the beginning of identity for individuals within that tradition" grounds the nations in the federation she has in mind (Ashcroft, 2017, p. 444). Hence, the basis of national identity is not restrictive but keeps changing. Finally, as Arendt's approving remarks on the French resistance movements that recognize the need to establish a federative structure of Europe and within its member states attest, her federalism is attentive to both external and internal needs of federalization and thus is far from self-contained nation and nationalism (Arendt, 1994, p. 114; Arendt, 2007b, p. 400; Lederman, 2019, p. 13). At any rate, though, what these interpretative engagements have assured is Arendt's strong interest in institutionalizing freedom and her sensible recognition of the importance of "some kind of organized community" for free politics where making “opinions significant and actions effective” occupies a central concern (Arendt, 1973, p. 294, p. 296).

Arendt's qualified endorsement of nationality for global federalism and her deep appreciation of the constitutional state render state agency a relevant topic for her international thoughts. The chief issue that these observations on Arendt's thinking raise is how to formulate a new concept of the state that reflects the equal demands of external and internal federalization against power centralization that is detrimental to free politics. In On Revolution and other later writings, Arendt refines the arguments she developed in her early works on federalism, offering novel accounts that outline the delegation process at multiple levels of politics through federated grassroots councils (Arendt, 1958, p. 32; Arendt, 2006b, pp. 240-273; Arendt, 1972, pp. 230-233). However, although Arendt's statements about the federated council system manifest needed nuance and complexity for fulfilling a new order of world 
politics, they have received a relative lack of attention in IR scholarship. The systematic IR work that seems to be most proximate to this topic is John Williams's analysis. Discovering enriching insights in Arendt's statements about plurality—the governing principle for political action-Williams sensibly points out the limit of the pluralist stream of the international society approach (Williams, 2002, p. 743; Williams, 2015, pp. 73-110). He finds it essential for "the international space in-between" to meet Arendt's standard of plurality, arguing that international institutions should be viewed as "devices for creating a space in-between, rather than ... as perimeter fences maintained and policed by a small political, diplomatic and military elite" (Williams, 2002, p. 752). Yet, Williams occasionally overstates Arendt's claims about the territorial borders of the state (Williams, 2005, pp. 208-209; cf. Williams, 2015, p. 56). In fact, the desirable direction of pluralistic international society he envisions, one that goes well beyond the formal diplomacy among state actors, is already implied in Arendt's councilbased federalism.

A careful examination of Arendt's statements about federalism reveals her distinctive approach to IR. The central aim of Arendt's international federalism is to shift attention to the international dimension in between states from both power from the above and power from the below. Arendt argues that the rudiments of a new concept of the state are found in the federal system. The rationale she provides is that federalism realizes a situation in which "power moves neither from above nor from below, but is horizontally directed so that the federated units mutually check and control their powers" (Arendt, 1972, p. 230). In the conventional IR context, power from above points to world government. To Arendt, international federation, opposite supernational governance, resists establishing a single hegemonic power to enforce an order for the whole world by cultivating a space for mutual deliberation among states. At the same time, federalism also avoids power moving from below, the condition of international anarchy in which the source of power solely lies in each sovereign 
state-leading to constant interstate competition for security (Arendt, 1972, p. 107; Arendt, 2005, p. 189).

The principle that federalism resists power both from above and from below also applies to internal federalization. Contra scholars who charge her thinking with being tainted by a naïve belief in the centrality of the state for international relations, Arendt's council-based federalism, similar to some approaches that have brought the question of representation to the fore in world politics, promotes a complex system of coordination at multiple layers of local politics (Kuper, 2004). For her, by creating "spaces of freedom" to incorporate new voices for change into the existing arrangements of political/legal judgment, federalist grassroots councils foster free politics far from sovereign statism. Equally notable, however, is that theorists who value Arendt's objection to sovereign power centralization often end up undermining her reservation about power from below at the local level of politics (Menga, 2014, pp. 313-326; Lederman, 2019, pp. 199-221). Arendt mentions that from the elementary republics citizens voluntarily form at the grassroots level, "the councilmen ... chose their deputies for the next higher council, and these deputies, again, were selected by their peers; they were not subject to any pressure either from above or from below" (Arendt, 2006b, p. 270). Thus, for Arendt, the council system goes through a delegation process that diffuses power.

Since delegation creates different levels in the council system, Arendt's council-based federalism renders it difficult to treat all units of federation as nominal. Arendt states that the council system forms a pyramid, though this differs from the typical authoritarian government (Arendt, 2006b, p. 270). The units of power conceived of in her council federalism, then, are not equal because a pyramidal government based on the council system suggests the presence of a highest level of delegation. Another crucial point regarding Arendt's internal federalization is that, by her remarks of "not from below," she intends to have her federalist model guarantee independence for each of the pyramid's layers of the council system. Operating with this multi-layered configuration of power, her 
council politics significantly departs from the sovereign state model that subjects all power sources to a central sovereign entity (Lederman, 2019, pp. 11-38; Kalyvas, 2008, pp. 254-291). However, although informed by the opinions of the actual people at the bottom of politics, Arendt's federalism opposes the situation in which representation and arrangement of internally diverse views at each stratum of the council system are subject to constant popular turbulence.

A key issue IR scholars face when exploring an international form of institution for Arendt's free politics is how to deal with the tension between higher and lower councils that her call for external and internal federalization generates. The tension is most likely to appear in international politics, as the deputies at the global council are torn between the expectations of representing their own people's diverse views and of working as competent diplomatic partners with other state representatives. Andreas Kalyvas is right to point out that Arendt's council system is based on mutual trust and that trust among individuals can serve to fill the gaps between the system's different layers (Kalyvas, 2008, pp. 280-283). However, making a solidarist case for globalism out of Arendt's reference to a “special trust" allegedly present at all levels of the council system is rather hasty because Arendt does not specify the scope of such trust and only confirms that the deputies "rested on nothing but the confidence of their equals" (Arendt, 2006b, p. 270). Confidence may exist in cases of equality between the deputies and either the people who select them or other deputies who meet them at the higher council. Yet, Arendt's statements about council-based federalism never fully clarify "the relationship between the delegates of the lower and those of the higher councils" (Kalyvas, 2008, p. 280). This ambiguity found in Arendt's attempt to institutionalize freedom points to complexity related to state agency, raising difficult questions such as this one: How much autonomy do state delegates have as diplomatic actors at the global council when balancing representing their people with being working partners of the delegates from other states? 


\section{Council Federalism for IR Theory}

Arendt's ambivalence regarding state agency is often viewed as a hurdle to articulating an IR version of her thoughts. Some scholars argue that "from the external standpoint there is not the difference that [Arendt] sometimes imagined between federal republics and nation-states," thereby concluding that her vision of free politics and desire to institutionalize it cannot extend beyond domestic politics (Arato \& Cohen, 2010, p. 162). Others are similarly critical yet propose a much more integrative form of international federalization by appealing to ideational or materialistic circumstances conducive to world cooperation, such as those fostered by a growing consensus on the efficacy of human rights standards or triggered by a fear of mutual destruction in the face of modern weaponry like nuclear weapons (Benhabib, 2007, pp. 454-459; Deudney, 2007, p. 162). However, as Douglas Klusmeyer aptly notes, Arendt's reluctance to spell out a clear model of international federation does not derive from some kind of oversight but closely relates to her sensitivity to the complex nature of issues on state agency and the highly contingent character of practical politics (Klusmeyer, 2009, p. 51). Indeed, Arendt's council-based federalism reveals her acute awareness of challenges and complexities that arise from simultaneously pursuing two demands of equality-inter-state equality against imperialism and intra-state equality against authoritarianism (Brown, 2013).

One can argue that the federalist idea Arendt proposes makes a special case of her thinking for IR because, while searching for a middle way of international discourse, it also resists any hubristic claim to fully reconcile the two competing demands of equality for free politics. In contrast to realist and communitarian theories of international politics, Arendt's thoughts do not view pursuing both anti-authoritarianism and anti-imperialism as contradictory. Her statements about "a world-wide federated structure" and the council system evince her strong interest in a complex system of coordination at multiple layers of politics, one that reduces the gap between the two claims of equality essential for maintaining desirable state agency (Arendt, 1968, p. 93; Arendt, 1972, p. 231). Contra 
some liberal IR theories, however, Arendt's thinking suggests that at the most fundamental level, such a gap is not fully reconcilable. Despite her strong objection to authoritarianism, Arendt's federalism does not consider individuals as the only conceivable actors for all levels of her free politics. In addition to her deep appreciation of the constitutional state's providing stability for politics and her idea of worldliness as an attitudinal quality of care for the public world, Arendt's accounts of resisting world tyranny give core attention to states constituting a pluralistic international order. Arendt's federalism oscillates between the demands of intra-state equality and inter-state equality while critically attending to the issue of who would be the constitutive actor in international politics.

Arendt scholars have certainly acknowledged the critical nature of Arendt's thinking. What informs Arendt's critical posture, Margaret Canovan attests, is her conception of the political, the fundamental base of which is the public worlds "born of the specific actions and agreements of particular men and dependent on continuing support for their survival" (Canovan, 1992, p. 248). Cognizant of the contingent aspect of public worlds and the limit of theorizing about politics in the face of such contingency, as Patricia Owens observes, Arendt hardly offers a blueprint for solving the contemporary problems of international politics (Owens, 2007, p. 118). Even in the form of federalism as a middle-ground discourse for IR, Arendt's international thoughts leave some specific issues less clear, bringing the task of clarification to actual citizens who deliberate about the future of their common spaces for freedom. Her intent in attending to the idea of federalism is not to entertain an imaginary point of complete equilibrium between the two competing demands of state equality but to generate questions for political actors regarding what they gain and lose from attending to each side of free politics.

Resonating with some of the debates on pluralism and solidarism in IR (Bain, 2018; Buzan, 2004, pp. 159-160; Levine \& McCourt, 2018), this elaboration of Arendt's thinking highlights how her equal appeal to agonistic action and institutional stability or informal and formal aspects of free politics 
is displayed in the international scene (Lee, 2020, pp. 12-19; Axtmann, 2006, pp. 111-117; Weinert, 2015, pp. 51-53). Her council-based federalism can best be characterized as a distinctive middle-way politics that treats two demands of state equality as "ideal types" along a continuum (Arendt, 1973, pp. 361-362, n.57; Arendt, 1979, p. 329; Baehr, 2010b, p. 26; Klusmeyer, 2009, p. 35). Understood this way, Arendt's ideas of power association and federation can serve as a critical ground for resisting not only rhetorical exaggeration of either anti-authoritarianism or anti-imperialism commonly seen in the contemporary context of international politics but also hubristic moments in IR theorizing that dismiss the fundamental complexity relating to state agency and the contingency of practical politics.

\section{Conclusion}

The common method of exploring the contemporary relevance of classical thinkers is isolating one strand of argument in a complicated body of work. Although an analytic articulation of this kind renders complex theorists more accessible for topical issues, it also makes their oeuvres onedimensional. Arendt's reception is not exceptional on this score, as Roy Tsao questions the adequacy of the approaches "treating her [works] themselves as little more than haphazard collections of aphoristic dicta" (Tsao, 2002, p. 98). Certainly, Arendt's accounts of agonistic action and the rise of the social occupy an important place in her thinking, but their real connotations can be captured only in the broad picture her free politics draws. The difficult task for Arendt scholars is to reflect the theoretical rigor found in her vision of free politics, characterized by what Dana Villa judges a "stunningly original synthesis of [political existentialism and civic republicanism]," while sorting out the practical implications of her thinking and the critical questions it raises for contemporary events and issues (Villa, 2007, p. 336).

For theorists who seek to implement Arendt's vision of free politics in international politics, additional challenges arise, as her thinking raises the crucial issues of power association and state 
agency. Action, which Arendt thinks is the seed of power formation, needs a constitutional referent for its reliable appearances. In her free politics, such an internal demand for stability to ensure institutionally articulated spaces for action faces the external demand to establish new relationships with others. Arendt's council-based federalism-her most specific institutional model for power association in free politics - acutely manifests her awareness of the fundamental complexity that lies in state agency, alluding to the tension diplomatic actors must experience at the global council between the needs to represent their own people and to become competent working partners with the delegates from other states or, more broadly, between two types of state equality against authoritarianism and imperialism.

Critical engagements with a variety of aspects of Arendt's international thoughts have already been suggested. As a way of synthesizing the discussion made so far, the following sketches Arendtian responses to three possible critiques of Arendt's thinking. To begin with, IR liberal theorists may view Arendt's concern about world tyranny as myopic and outdated because contemporary discourse on global governance is properly informed about this danger of hegemonic forces and instead promotes desirable complex processes of public deliberations at a variety of political institutions and social networks (Benhabib, 2002, p. 560; Scheuerman, 2011, p. 154; cf. Ronzoni, 2017, pp. 204-205). Yet, considering research findings that the liberal bias of some moral, institutional criteria has prevented serious endeavors to engage with the local (Brown, 2012, pp. 224-226; Randazzo, 2019, pp. 54-84; Baron et al., 2019), the Arendtian sensitivity to global hegemony and depoliticization has a particular resonance in IR. Her thinking-not a polar opposite to liberal values such as human rights—serves as a critical parameter in reframing the international discourse on global and local encounters.

In addition, scholars who stand on so-called "positivism," as well as those who seek to elevate the policy relevance of security studies (Desch, 2015), would point out the lack of methodological rigor and practicality in Arendt's international thoughts. Using Robert Cox's distinction between 
problem-solving and critical theories, one can easily find that Arendt's thoughts are close to the latter, though they have distinctive features that do not fit easily with the Marxian component immanent in the arguments of critical IR studies (Cox, 1981; Canovan, 1992, pp. 63-98; Weisman, 2013). Yet, even conceding the fundamentally critical orientation of Arendt's thinking, there is no reason to dismiss the call to explore the practical implications her critique entails. In fact, Arendt's writings were always informed by concrete historical analyses of modern politics and society (Owens, 2007, p. 31). Thus, translating the "macro" goal of Arendt's theory-free politics-into "micro"-level political engagements is worth pursuing, albeit with caution not to reduce her thinking to the task of offering strategic solutions to security issues.

Finally, scholars of radical agonism may view Arendt's international federation as insufficiently critical. The driving idea is that the threat of neoliberalism accompanied by a mega-state that fuses governmental and corporate modes of power is overwhelming to contemporary politics; thus, the required political practice is one of sheer contestation or indeterminacy that challenges the basic terms of the construction and relations of the global and the local set by the dominant neoliberal framework (Wolin, 2016, p. 111; Zanotti, 2013, pp. 297-299). There is an empirical question of whether and to what extent existing institutions and sites of power are trapped within neoliberalism. Aside from this, one can also raise questions about the politics of resistance envisioned by radical agonism by comparing it with Arendt's appreciation of any endeavors to maintain a politically engaged care for the world. Her thinking can benefit from those critical engagements seeking to reveal unnoticed power operations in everyday politics. Equally for radical agonists, Arendt's attempt to direct the energies and potentials of agon to sustain the bases of free politics as practiced by diverse equals in an institutionally articulated space is worth proper attention.

Many of Arendt's seemingly inconsistent statements, as Jerome Kohn aptly points out, can be attributed to "the inherent difficulty of what she sought to understand" (Kohn, 2005, xix). Her political 
thoughts are neither defeatism nor triumphalism. The res publica Arendt envisions is not amorphous or indeterminate, even when it is viewed alongside her dismal accounts of the rise of the social in the modern world. Instead, her thinking shows acute understanding of both internal and external difficulties that republics face as "islands of freedom." She thereby directs attention to the fundamental challenge in free politics: balancing domestic and international demands for equality. Bringing IR topics like state agency into conversation with her works generates illuminating questions for Arendt scholarship. Likewise, the ongoing debate on agonistic and institutional or existential and republican features of Arendt's thoughts can provide crucial insights into critical studies of international politics. 


\section{References}

Amin, S. (2014). Capitalism in the age of globalization: The management of contemporary society. London: Zed Books.

Arato, A., \& Cohen, J. (2010). Banishing the sovereign? Internal and external sovereignty in Arendt. In In S. Benhabib, R. Tsao, \& P. Verovšek (Eds.), Politics in dark times: Encounters with Hannah Arendt (pp. 137-171). Cambridge: Cambridge University Press.

Arendt, H. (1958). Totalitarian imperialism: Reflections on the Hungarian Revolution. Journal of Politics, 20, 5-43.

Arendt, H. (1963). Eichmann in Jerusalem: A report on the banality of evil. New York: Viking.

Arendt, H. (1968). Men in dark times. New York: Harcourt.

Arendt, H. (1972). Crises of the republic, New York: Harcourt.

Arendt, H. (1973). The origins of totalitarianism. New York: Harcourt.

Arendt, H. (1979). On Hannah Arendt. In M. Hill (Ed.), Hannah Arendt: The recovery of the public world (pp. 301-339). New York: St. Martin's Press.

Arendt, H. (1982). Lectures on Kant's political philosophy (R. Beiner, Ed.). Chicago: The University of Chicago Press.

Arendt, H. (1994). Essays in understanding, 1930-1954 (J. Kohn, Ed.). New York: Harcourt.

Arendt, H. (1996). Love and Saint Augustine. Chicago: The University of Chicago Press.

Arendt, H. (1998). The buman condition. Chicago: The University of Chicago Press.

Arendt, H. (2005). The promise of politics (J. Kohn, Ed.). New York: Schocken Books.

Arendt, H. (2006a). Between past and future: Eight exercises in political thought. New York: Penguin Books.

Arendt, H. (2006b). On revolution. New York: Penguin Books.

Arendt, H. (2007a). The great tradition: II. Ruling and being ruled. Social Research, 74, 941-954.

Arendt, H. (2007b). The Jewish writings. New York: Schocken Books.

Arendt, H. \& Jaspers, K. (1992). Hannah Arendt and Karl Jaspers correspondence 1926-1969 (L. Kohler \& H. Saner, Eds.). New York: Harcourt.

Arendt, H. \& Scholem, G. (2017). The correspondence of Hannah Arendt and Gershom Scholem (M. Knott, Ed.). Chicago: The University of Chicago Press. 
Ashcroft, C. (2017). Jewishness and the problem of nationalism: A genealogy of Arendt's early political thought. Modern Intellectual History, 14, 421-449.

Ashcroft, C. (2018). The polis and the res publica: Two Arendtian models of violence. History of European Ideas, 44, 128-142.

Axtmann, R. (2006). Globality, plurality and freedom: the Arendtian perspective. Review of International Studies, 32, 93-117.

Ba, O. (2017). International justice and the postcolonial condition. Africa Today, 63, 44-62.

Baehr, P. (2010a). China the anomaly: Hannah Arendt, totalitarianism, and the Maoist regime. European Journal of Political Theory, 9, 267-286.

Baehr, P. (2010b). Hannah Arendt, totalitarianism, and the social sciences. Stanford, CA: Sanford University Press.

Bain, W. (2018). The pluralist-solidarist debate in the English School. Oxford Research Encyclopedia of International Studies. doi: 10.1093/acrefore/9780190846626.013.342.

Barder, A., \& Debrix, F. (2011). Agonal sovereignty: Rethinking war and politics with Schmitt, Arendt and Foucault. Philosophy \& Social Criticism, 37, 775-793.

Bargués-Pedreny, P. (2017). Connolly and the never-ending critiques of liberal peace: From the privilege of difference to vorarephilia. Cambridge Review of International Affairs, 30, 216-234.

Baron, I. Z., Havercroft, J., Kamola, I., Koomen, J., Murphy, J., \& Prichard, A. (2019). Liberal pacification and the phenomenology of violence. International Studies Quarterly, 63, 199-212.

Beiner, R. (2000). Arendt and nationalism. In D. Villa (Ed.), The Cambridge companion to Hannah Arendt (pp. 44-62). Cambridge: Cambridge University Press.

Bell, D. (2017). Political realism and international relations. Philosophy Compass, 12, 1-12. doi: $10.1111 /$ phc3.12403.

Benhabib, S. (1996). The reluctant modernism of Hannah Arendt. Thousand Oaks, CA: Sage Publication.

Benhabib, S. (2002). Political geographies in a global world: Arendtian reflections. Social Research, 69, 539-566.

Benhabib, S. (2007). Democratic exclusions and democratic iterations: Dilemmas of "just membership" and prospects of cosmopolitan federalism. European Journal of Political Theory, 6, 445462.

Benhabib, S. (2008). Another cosmopolitanism. Oxford: Oxford University Press.

Benhabib, S. (2009). Claiming rights across borders: International human rights and democratic sovereignty. American Political Science Review, 104, 691-704. 
Benhabib, S. (2010). International law and human plurality in the shadow of totalitarianism: Hannah Arendt and Raphael Lemkin. In S. Benhabib, R. Tsao, \& P. Verovšek (Eds.), Politics in dark times: Encounters with Hannah Arendt (pp. 219-243). Cambridge: Cambridge University Press.

Birmingham, P. (2006). Hannah Arendt and buman rights: The predicament of common responsibility. Indianapolis, IN: Indiana University Press.

Birmingham, P. (2014). Hannah Arendt's philosophy of law approach to international criminal law. International Criminal Law Review, 14, 695-716.

Björkdahl, A., \& Höglund, K. (2013). Precarious peacebuilding: Friction in global-local encounters. Peacebuilding, 1, 289-299.

Brown, C. (2013). Authoritarianism, anti-imperialism, and intervention: The precariousness of the middle ground. In C Navari (Ed.), Ethical reasoning in international affairs: Arguments from the middle ground (pp. 203-221). New York: Palgrave.

Brown, C. (2015). International society, global polity. London: Sage.

Brown, G. W. (2012) The constitutionalization of what? Global Constitutionalism, 1, 201-228.

Buzan, B. (2004). From international to world society? Cambridge: Cambridge University Press.

Canovan, M. (1974). The political thought of Hannah Arendt. London: J. M. Dent.

Canovan, M. (1992). Hannah Arendt: A reinterpretation of her political thought. Cambridge: Cambridge University Press.

Canovan, M. (1996a). Hannah Arendt as a conservative thinker. In L. May \& J. Kohn (Eds.), Hannah Arendt: Twenty years later (pp. 11-32). Cambridge, MA: The MIT Press.

Canovan, M. (1996b). Nationhood and political theory. Cheltenham, UK: Edward Elgar Publication.

Canovan, M. (1999a). Is there an Arendtian case for the nation-state? Contemporary Politics, 5, 103-119.

Canovan, M. (1999b). Lasting institutions: Arendtian thoughts on nations and republics. Graduate Faculty Philosophy Journal, 21, 133-151.

Chandler, D. (2010). International statebuilding: The rise of post-liberal governance. London: Routledge.

Cohen, J. (1996). Dilemmas of Arendtian republicanism. Constellations, 3, 164-189.

Coles, R. (2016). Visionary pragmatism: Radical and ecological democracy in neoliberal times. Durham, NC: Duke University Press.

Cox, R. (1981). Social forces, states and world orders: Beyond international relations theory. Millennium: Journal of International Studies, 10, 126-155 
d'Entreves, M. (1994). The political philosophy of Hannah Arendt. London: Routledge.

Desch, M. (2015). Technique trumps relevance: The professionalization of political science and the marginalization of security studies. Perspectives on Politics, 13, 377-393.

Deudney, D. (2007). Bounding power: Republican security theory from the polis to the global village. Princeton, NJ: Princeton University Press.

Doyle, M. (1983). Kant, liberal legacies, and foreign affairs. Philosophy \& Public Affairs, 12, 205-235.

Frazer, E., \& Hutchings, K. (2008). On politics and violence: Arendt contra Fanon. Contemporary Political Theory, 7, 90-108.

Goldoni, M., \& McCorkindale, C. (Eds.). (2012). Hannah Arendt and law. Oxford: Hart Publishing.

Goodman, J. (2017). Nationalism as a social movement. Oxford Research Encyclopedia of International Studies. doi: 10.1093/acrefore/9780190846626.013.267.

Gourevitch, P., Lake, D., \& Stein, J. G. (Eds.). (2012). The credibility of transnational NGOs: When virtue is not enough. Cambridge: Cambridge University Press.

Grunenberg, A., \& Daub, A. (2007). Arendt, Heidegger, Jaspers: Thinking through the breach in tradition. Social Research, 74, 1003-1028.

Gündoğdu, A. (2015). Rightlessness in an age of rights: Hannah Arendt and the contemporary struggles of migrants. Oxford: Oxford University Press.

Hall, I. (2011). The triumph of anti-liberalism? Reconciling radicalism to realism in international relations theory. Political Studies, 9, 42-52.

Hayden, P. (2009). Political evil in a global age: Hannah Arendt and international theory. London: Routledge.

Hayden, P, \& Saunders, N. (2019). Solidarity at the margins: Arendt, refugees, and the inclusive politics of world-making. In K. Hiruta (Ed.), Arendt on freedom, liberation, and revolution (pp. 171-199). New York: Palgrave.

Hinchman, L., \& Hinchman, S. (1991). Existentialism politicized: Arendt's debt to Jaspers. The Review of Politics, 53, 435-468.

Hiruta, K. (Ed.). (2019). Arendt on freedom, liberation, and revolution. New York: Palgrave.

Honig, B. (1993a). Political theory and the displacement of politics. Ithaca, NY: Cornell University Press.

Honig, B. (1993b). The politics of agonism. Political Theory, 21, 528-33.

Honig, B. (2009). Emergency politics: Paradox, law, democracy. Princeton, NJ: Princeton University. 
Horst, C., \& Lysaker, O. (2019). Miracles in dark times: Hannah Arendt and refugees as "vanguard." Journal of Refugee Studies. doi: 10.1093/jrs/fez057.

Howes, D. (2013). The failure of pacifism and the success of nonviolence. Perspectives on Politics, 11, 427-446.

Ingram, J. (2008). What is a "right to have rights"? Three images of the politics of human rights." American Political Science Review, 102, 401-416.

Jackson, P. (2004). Hegel's house of "people are states too.” Review of International Studies, 30, 281287.

Jay, M. (1986). Permanent exiles: Essays on the intellectual migration from Germany to America. New York: Columbia University Press.

Jean-Klein, I., \& Riles, A. (2005). Anthropology and human rights administrations. Political and Legal Anthropology Review, 28, 173-202.

Jones, B. (2013). Slavery, finance and international political economy: Postcolonial reflections. In S. Seth (Ed.), Postcolonial theory and international relations (pp. 49-69). London: Routledge.

Kalyvas, A. (2008). Democracy and the politics of the extraordinary: Max Weber, Carl Schmitt, and Hannah Arendt. Cambridge: Cambridge University Press.

Kant, I. (1983). Perpetual peace and other essays (T. Humphrey, Trans.). Indianapolis, IN: Hackett Publishing.

Kateb, G. (1984). Hannah Arendt: Politics, conscience, evil. Totowa, NJ: Rowman \& Allanheld.

Kateb, G. (2010). Existential values in Arendt's treatment of evil and morality. In S. Benhabib, R. Tsao, \& P. Verovšek (Eds.), Politics in dark times: Encounters with Hannah Arendt (pp. 342-373). Cambridge: Cambridge University Press.

Keenan, A. (1994). Promises, promises: The abyss of freedom and the loss of the political in the work of Hannah Arendt. Political Theory, 22, 297-322.

Klusmeyer, D. (2005). Hannah Arendt's critical realism: Power, justice, and responsibility. In A. Lang \& J. Williams (Eds.), Hannah Arendt and international relations: Readings across the lines (pp. 113178). New York: Palgrave.

Klusmeyer, D. (2009). Hannah Arendt's case for federalism. Publius: The Journal of Federalism, 40, 31 58.

Kohn, J. (2005). Introduction. In J. Kohn (Ed.), The promise of politics (pp. vii-xxxiii). New York: Schocken Books.

Kohn, M. (2013). Postcolonialism and global justice. Journal of Global Ethics, 9, 187-200. 
Krause, M. (2008). Undocumented migrants: An Arendtian perspective. European Journal of Political Theory, 7, 331-348.

Kuper, A. (2004). Democracy beyond borders: Justice and representation in global institutions. Oxford: Oxford University Press.

Lang, A. (2002). Agency and ethics: The politics of military intervention. Albany, NY: State University Press of New York.

Lang, A. (2008). Evil, agency, and punishment. In Renée Jeffery (Ed.), Confronting evil in international relations: Ethical responses to problems of moral agency (pp. 89-114). New York: Palgrave.

Lang, A., \& Williams, J. (Eds.). (2005). Hannah Arendt and international relations: Readings across the lines. New York: Palgrave.

Lederman, S. (2019). Hannah Arendt and Participatory Democracy. New York: Palgrave.

Lee, S. (2020). The real promise of federalism: A case study of Arendt's international thought. European Journal of Political Theory. doi: 10.1177/1474885120906059.

Lee, S. (2021). Building communities of peace: Arendtian realism and peacebuilding. Polity, 53, 75-100.

Levine, D., \& McCourt, D. (2018). Why does pluralism matter when we study politics? A view from contemporary international relations. Perspectives on Politics, 16, 92-109.

Luban, D. (2015). Arendt on the crime of crimes. Ratio Juris, 28, 307-325.

Macready, J. (2016). Hannah Arendt and the political meaning of human dignity. Journal of Social Philosophy, 47, 399-419.

Markell, P. (2011). Arendt's work: On the architecture of The Human Condition. College Literature, 38, $15-44$.

McGowan, J. (1997). Must politics be violent? Arendt's utopian vision. In C. Calhoun \& J. McGowan (Eds.), Hannah Arendt and the meaning of politics (pp. 263-296). Minneapolis, MN: University of Minnesota Press.

Menga, F. (2014). The seduction of radical democracy: Deconstructing Hannah Arendt's political discourse. Constellations, 21, 313-326.

Miller, D. (2007). National responsibility and global justice. Oxford: Oxford University Press.

Miller, D. (2008). Republicanism, national identity, and Europe. In C. Laborde \& J. Maynor (Eds.), Republicanism and political theory (pp. 133-158). Hoboken, NJ: Wiley-Blackwell.

Miller, D. (2016). How "realistic" should global political theory be? Some reflections on the debate so far. Journal of International Political Theory, 12, 217-233. 
Mitchell, A. (2010). Peace beyond process? Millennium: Journal of International Studies, 38, 641-664.

Mitchell, A. (2014). Only human? A worldly approach to security. Security Dialogue, 45, 5-21.

Muldoon, J. (2016). Arendtian principles. Political Studies, 64, 121-135.

Neumann, I. (2004). Beware of organicism: The narrative self of the state. Review of International Studies, 30, 259-267.

Owens, P. (2007). Between war and politics: International relations and the thought of Hannah Arendt. Oxford: Oxford University Press.

Owens, P. (2010). Walking corpses: Arendt on the limits and possibilities of cosmopolitan politics. In C. Moore and C. Farrands (Eds.), International relations theory and philosophy: Interpretive dialogues (pp. 72-82). London: Routledge.

Owens, P. (2011). The return of realism? War and changing concepts of the political. In H. Strachan and S. Scheipers (Eds.), The changing character of war (pp.484-502). Oxford: Oxford University Press.

Owens, P. (2012). Not life but the world is at stake: Hannah Arendt on citizenship in the age of the social. Citizenship Studies, 16, 297-307.

Parekh, B. (1984). Hannah Arendt and the search for a new political philosophy. New York: Palgrave.

Pitkin, H. (1998). The attack of the blob: Hannah Arendt's concept of the social. Chicago: The University of Chicago Press.

Randazzo, E. (2017). Beyond liberal peacebuilding. London: Routledge.

Rawls, J. (1999). A theory of justice. Cambridge, MA: Harvard University Press.

Reader, S. (2007). Cosmopolitan pacifism. Journal of Global Ethics, 3, 87-193.

Ringmar, E. (1996). On the ontological status of the state. European Journal of International Relations, 2, 439-466.

Robinson, A., \& Tormey, S. (2009). Resisting 'global justice': Disrupting the colonial 'emancipatory' logic of the West. Third World Quarterly, 30, 1395-1409.

Ronzoni, M. (2017). Republicanism and global institutions: Three desiderata in tension. Social Philosophy \& Policy, 34, 186-208.

Rubin, G. (2015). From federalism to binationalism: Hannah Arendt's shifting Zionism. Contemporary European History, 24, 393-414.

Schaap, A. (2005). Political reconciliation. London: Routledge.

Scheuerman, W. (2011). The realist case for global reform. London: Polity. 
Schmitt, C. (1996). The concept of the political (J. H. Lomax, Trans.). Chicago: The University of Chicago Press.

Selinger, W. (2016). The politics of Arendtian historiography: European federation and The Origins of Totalitarianism. Modern Intellectual History, 13, 417-446.

Shinko, R. (2008). Agonistic peace: A postmodern reading. Millennium: Journal of International Studies, 36, 473-491.

Tsao, R. (2002). Arendt against Athens: Rereading The Human Condition. Political Theory, 30, 97-123.

Valentini, L. (2012). Ideal vs. non-ideal theory: A conceptual map. Philosophy Compass, 7, 654-664.

Villa, D. (1996). Arendt and Heidegger: The fate of the political. Princeton, NJ: Princeton University Press.

Villa, D. (1999). Politics, philosophy, terror: Essays on the thought of Hannah Arendt. Princeton, NJ:

Princeton University Press.

Villa, D. (2007). Arendt, Heidegger, and the tradition. Social Research, 74, 983-1002.

Villa, D. (2008a). Public freedom. Princeton, NJ: Princeton University Press.

Villa, D. (2008b). Political violence and terror: Arendtian reflections. Ethics \& Global Politics, 1, $97-$ 113.

Volk, C. (2010). From nomos to lex: Hannah Arendt on law, politics, and order. Leiden Journal of International Law, 23, 759-779.

Volk, C. (2015). Arendtian constitutionalism: Law, politics and the order of freedom. Oxford: Hart Publishing.

Waldron, J. (2000). Arendt's constitutional politics. In D. Villa (Ed.), The Cambridge companion to Hannah Arendt (pp. 201-219). Cambridge: Cambridge University Press.

Weber, C. (1998). Performative states. Millennium: Journal of International Studies, 27, 77-95.

Weinert, M. (2015). Making human: World order and the global governance of human dignity. Ann Arbor, MI: University of Michigan Press.

Weisman, T. (2013). Hannah Arendt and Karl Marx: On totalitarianism and the tradition of Western political thought. Lanham, MD: Lexington Books.

Wenman, M. (2013). Agonistic democracy: Constituent power in an era of globalization. Cambridge: Cambridge University Press.

Wight, C. (2004). State agency: Social action without human activity? Review of International Studies, 30, 269-280. 
Williams, J. (2002). Territorial borders, toleration and the English School. Review of International Studies, 28, 748-756.

Williams, J. (2005). Hannah Arendt and the international space in-between? In A. Lang \& J. Williams (Eds.), Hannah Arendt and international relations: Readings across the lines (pp. 199-220). New York: Palgrave.

Williams, J. (2015). Ethics, diversity, and world politics: Saving pluralism from itself? Oxford: Oxford University Press.

Wolin, R. (1990). The politics of being: The political thought of Martin Heidegger. New York: Columbia University Press.

Wolin, S. (1994). Hannah Arendt: Democracy and the political. In L Hinchman and S Hinchman (Eds.), Hannah Arendt: Critical essays (pp. 289-306). Albany, NY: State University of New York Press.

Wolin, S. (2016). Fugitive democracy and other essays (N. Xenos, Ed.). Princeton, NJ: Princeton University Press.

Young-Bruehl, E. (2004). Hannah Arendt: For love of the world (2nd ed.). New Haven, CT: Yale University Press.

Zanotti, L. (2013). Governmentality, ontology, methodology: Re-thinking political agency in the global world. Alternatives: Global, Local, Political, 38, 288-304. 